CZU: 811.135.1'373.232

https://doi.org/10.52505/lecturi.2021.05.18

\title{
NUME DE FAMILIE DE ORIGINE TOPONIMICĂ
}

\author{
Viorica RĂILEANU \\ Institutul de Filologie Română „Bogdan Petriceicu-Hasdeu”, Chișinău
}

Rezumat. Numele de familie de origine toponimică constituie o categorie importantă a antroponimiei. Apariția lor a fost determinată de anumiți factori sociali, economici, juridici. Aceste nume ne amintesc cât de veche și devotată este relația dintre loc (moșie, casă, sat, oraș, țară) şi om.

Originea toponimică a acestor nume este exprimată prin anumite modalități. Una dintre ele este derivarea cu sufixe.

Cuvinte-cheie: antroponimie, nume de familie, derivare, sufix, toponim.

Abstract. The surnames with toponymic origin are an important category of anthroponymy. Their emergence was determined by certain social, economic and legal factors. These names remind us how old and devoted is the relationship between place (estate, house, village, city, country) and human.

The toponymic origin of these names is expressed in certain ways, one of them is the derivation using the suffixes.

Keywords: anthroponymy, surname, derivation, suffix, toponym.

Numele de familie de origine toponimică constituie o categorie importantă în onomastica românească. Aceste nume, arătând originea sau apartenența locală, „leagă individul de pământul, de casa sau domeniul unde el locuiește, de localitatea sau țara de unde este originar" (Goicu, 1996, p. 40). Este evident că un nume de familie se poate forma de la un nume toponimic doar în cazul când acesta există deja.

Albert Dauzat menţionează că numele de familie provenite de la „,numiri geografice" sunt răspândite în toate țările din Europa Occidentală: Spania, Franţa, Germania, unde feudalismul şi-a exercitat puterea sa maximală (Dauzat, 1928, p. 85). În epoca feudală, numele proprietăţii era mai răspândit decât prenumele. Apariţia numelor de familie la toate popoarele era condiţionată de apariţia proprietăţii. Or, primele nume de familie oficiale s-au format de la denumirea geografică (moşie, sat etc.) sau de la un termen topografic care se afla în vecinătatea casei familiare ca: 
deal, dumbravă, pădure, râu, movilă etc. Astfel, relația toponim $\rightarrow$ antroponim se dovedește a fi o relație veche și devotată. Şt. Paşca susţine că numele ce au „calificative de origine”, ocupă un loc important în ,sistemul antroponomastic documentar" (Paşca, 1936, p. 87-88), precedând întrebuințarea patronimelor şi matronimelor.

Fiecărei limbi îi sunt specifice anumite modalităţi de exprimare a originii toponimice a numelor.

În limba română, numele în discuţie se prezintă ca nume derivate, formate prin mijloace specifice, exprimate fie prin nume de locuri precedate de prepoziții (Dinjos), fie prin derivare cu sufixe. Cele mai multe derivate sunt formate cu ajutorul sufixului -eanu ${ }^{1}(<$ v. sl. -ianinŭ, -janinŭ) (Popescu, 1960, p. 216). Sufixul a intrat în limba română odată cu numele slave de locuitori și este cel mai vechi sufix pentru formarea numelor de locuitori (Goicu, Goicu-Cealmof, 2010, p. 170).

Acest model de formare a numelor de familie a fost impus pe cale oficială, fapt atestat într-un document din anul 1680, în care este notat că domnitorul Şerban Cantacuzino a dat ordin ca fiecărui cetăţean să i se adauge pe lângă prenume şi un nume ,cel ce are moşie sau sub a lui putere cu temei moştenit vre-un sat, să-şi pue nomele satului adăogându-i scurtimea ...-eanu (...). Aşa pronomele unui român este Ioan şi are moşia Plop, prin adăugirea la Plop scurtimea -eanu, face Plopeanu şi cu Ioan, va fi Plopeanu Ioan.” (Paşca, 1936, p. 62).

Un factor care a generat denominarea persoanelor după locul de origine a fost determinat de mișcările de populație, frecvent întâlnite, altă dată, între așezările omenești. Acest proces s-a produs din diverse motive social-economice: „fărâmițarea obștii sătești și separarea satelor aflate într-un singur hotar; ,,roirea satelor"; popularea sau repopularea unor teritorii ,pustii”; colonizarea pământurilor libere cu populație din alte regiuni sau țări; împroprietărirea țăranilor etc.” (Eremia, 1970, p. 110). Frecvența numelor de sate în calitate de supranume coincide cu perioada migrației. „Aria în care se regăsește un nume de localitate ca nume de familie este proporțională cu importanța localității. O persoană originară dintr-un sat nu va primi numele acestuia ca supranume decât într-o regiune unde satul este cunoscut, deci într-o zonă foarte limitată." (Goicu, 1996, p. 40). Astfel, cei care se mutau cu traiul dintr-o localitate în alta erau mai lesne de identificat după numele locurilor de baștină, după localitățile de proveniență: Câmpeanu < Câmpeni, Bujoreanu $<$ Bujor etc. Nume de felul acesta nu puteau fi purtate de persoanele originare dintr-un sat, care erau numite, de obicei, câmpeni, bujoreni.

$\mathrm{Ca}$ reflex al migrației locuitorilor, sufixul -eanu a devenit foarte productiv în limba română, formând derivate de la oiconime, nume de sate: Bădiceanu (20) ${ }^{2}$ $<$ Bădiceni, Bratuşanu (8) < Brătușeni, Bujoreanu (177) < Bujor, Cărpineanu

\footnotetext{
${ }^{1}$ Sufixul se întâlnește și cu forma nearticulată -ean și formele -ian $(u)$, -an( $u$ ).

${ }^{2}$ Cifra reprezintă frecvența numelui pe întreg teritoriul Republicii Moldova.
} 
(82) < Cărpineni, Chetroșeanu (4) < Chetroșeni, Chiperceanu (39) < Chiperceni, Cobâleanu (1) < Cobîlea, Cojușneanu (185) < Cojușna, Colicăuțanu (1) (var. Colincăuțanu (17) < Colicăuț, Curluceanu $<$ Curluceni (azi Făgureni), Fundureanu (71) < Fundurii (Vechi), Lăpuşneanu (105) < Lăpușna, Lozoveanu (14) < Lozova, Medeleanu (28) < Medeleni, Mereșanu (3) < Mereșeni, Pîrlițeanu (112) < Pîrlița, Pociumbeanu (2) < Pociumbeni, Slobozeanu (105) < Slobozia, Surchiceanu (26) $<$ Surchiceni, Suruceanu (949) < Suruceni, Visterniceanu $(120)<$ Visterniceni $^{3}$ (Dron, 1995). Vorniceanu (39) < Vorniceni etc.; nume de orașe: Bîrlădeanu (477) < Bârlad, Braşoveanu (680) < Brașov, Brăileanu (187) < Brăila, Căinăreanu (172) < Căinari, Durleșteanu (68) < Durlești, Gabroveanu (18) < Gabrovo, Glodeanu (304) $<$ Glodeni, Ieșanu (127) < Iași, Orheianu (16) < Orhei, Suceveanu (85) < Suceava, Tecuceanu (57) < Tecuci, Vasluian (340) < Vaslui etc.

Din sfera oiconimicelor fac parte și numele unor vechi locuințe, construcții, instalații, edificate uneori pe locurile virane, nepopulate, alteori în jurul unor cătune sau locuințe izolate, servind ca loc de adăpost și apărare de intemperii sau de primejdii" ${ }^{4}$ : Bordei (< bordei „locuință mică, rudimentară”), Budă ( $<$ budă „construcție de lemn în pădure”), Câșlă (< câşlă ,așezare de păstori; stână”), Cocioabă (< cocioabă ,,bordei”), Colibă (< colibă „locuință a ciobanilor; adăpost provizoriu pentru oameni și, rar, pentru animale”), Odaie (< odaie „așezare gospodărească izolată de sat; fermă mică, târlă de vite; colibă servind de adăpost provizoriu pescarilor, ciobanilor sau muncitorilor agricoli în timpul lucrului"), Seliște (< seliște „locul pe care fusese sau pe care era așezat un sat; vatra satului”), Stână (< stână ,aşezare păstorească de vară, la munte sau în afara satului, unde se adăpostesc oile şi ciobanii”), Șură (< şură ,strungă (la stână); clădire anexă într-o gospodărie"), Târlă (< târlă „loc împrejmuit şi neacoperit, unde se odihnesc vitele sau oile") etc. La început, aceste așezări erau populate de toată familia, mai târziu, fiind părăsite din diverse motive (mai ales din necesități materiale), au devenit nişte anexe economice ale satelor sau ale gospodăriilor individuale. Persoanele venite de pe aceste locuri erau numite Bordeianu (927) (var. Bordeian), Budeanu (975) (var. Budean, Budianu, Budian), Cîșleanu (127) (var. Câșleanu, Câșlean, Cîş̧lean), Colibanu (6) (var. Coliban), Cociobanu (59) (var. Cocioban), Selișcean (2) (var. Selişcian) etc.

Teritoriul Moldovei este cuprins între adevărate hotare naturale, formate de fluviile Nistru şi Prut. În interior, această zonă e străbătută în toate direcţiile de mai multe râuri şi râuleţe, cu lacuri, bălți, lunci aşezate în văile lor. În totalitate, rețeaua hidrografică este reprezentată de circa 5000 de cursuri de apă. Toponimia cuprinde

\footnotetext{
${ }^{3}$ Visterniceni, sat la origine, care cu timpul a devenit o mahala a Chișinăului.

${ }^{4}$ Unele atestate astăzi ca nume de localități: Buda, Câșla, Odaia, Seliște etc.
} 
circa 5\% de nume topice cu caracter hidronimic. De la fiecare denumire de râuri mai mari (Cogâlnic, Nistru, Prut, Răut, Sireț etc.) au derivat câte unul sau mai multe nume de sate (Cogîlniceni, Nistreni, Pruteni, Răuțel, Sireți etc.), așezate pe cursul acestor râuri, care au determinat, la rândul lor, o bogată antroponimie: Cogîlniceanu (152) (var. Cogîlnicean, Cogîlnician), Copăcianu (259), Nistreanu (503) (var. Nistrean, Nistrian, Nistrianu, Dnistrean), Pruteanu (1595) (var. Prutean, Prutian, Prutianu), Sirețanu (214) (var. Sirețeanu). Pe lângă aceasta, pe râul Nistru sunt așezate 170 de sate, pe Prut - 150, pe Răut - 70, pe Bâc - 40, pe Botna 30 etc., majoritatea având la bază denumiri ce redau caracteristica principală a zonei: Bălți, Budăi, Bulboaca, Bulhac, Cișmea, Gârla (azi redenumit în Costești), Iezăreni, Izvoare, Izvoreni, Lunca, Ocnița, Vădeni etc. Numele formate de la aceste toponime sunt: Bălțeanu (2), Bahneanu (17), Budăianu (79), Bulboceanu (2), Gîrleanu (519), Izăreanu (42), Izvoreanu (120) (var. Izvorean), Luncan (1), Ocniţanu (7) (var. Ocnițan), Vădeanu (23) (var. Vadeanu) etc. Câteva antroponime atestate fac trimitere la o proveniență mai îndepărtată: Crișan (14) (var. Crisan) < Criș, Jianu (16) < Jiu etc.

Semnificativ este și numărul numelor de familie create de la nume topice de origine oronimică sau floronimică: Cîmpeanu (14) (var. Câmpan, Câmpeanu, Cîmpan, Cîmpanu), Codreanu (3370), Deleanu (252) (var. Delean, Deleanov), Dumbrăveanu (211) (var. Dumbrăvanu, Dumbrăvan, Dumbraveanu, Dumbravan, Dumbravanu), Hîrtopanu (7) (var. Hîrtopan), Holman (1), Măgureanu (22) (var. Măgurean), Movileanu (802) (var. Movilean, Movilianu, Movilian), Plopeanu (4) (var. Plopan), Pădureanu (164) (var. Pădurean, Padurean, Padureanu), Rîpeanu (1) (var. Râpan), Ulmanu (59) (var. Ulman), Văleanu (131) (var. Valean, Valeanu) etc.

Mai puține sunt numele de familie care au la bază denumiri de regiuni, provincii, zone: Ardeleanu (369) (var. Ardelean, Ardelian, Ardelianu, Ardeliean), Dobrogeanu (34) (var. Dobrojan, Dobrojanu, Dobrojean), Basarabeanu (4) Moldoveanu (171) (var. Moldovean, Moldovan, Moldovanov, Moldovanu), Moțoianu (38), (var. Moțcan), Munteanu (15078) (var. Muntean, Muntian, Muntenu, Muntianu, Muntianov), Mureșanu (6), Olteanu (498) (var. Oltean, Oltianu), Podoleanu (340) (var. Podolean, Podolian), Ungureanu (6422) (var. Ungurean, Ungurian, Ungurianu, Ungurenu), Vrînceanu (567) (var. Vrîncean, Vrîncianu, Vrîncian, Vrânceanu, Vrâncean), Zaporojan (2241) (var. Zaporojanu, Zaporojeanu) etc.

O categorie de nume de familie de origine toponimică, cu o frecvență foarte redusă, are la bază apelative topice. Folosite în funcţie onimică, au un caracter descriptiv: Bahnă (180), Balta (484), Budăi (128), Bulhac (492), Bulboacă (134), Cîmpu (69), Codru (30), Dumbravă (521), Gîrlă (156), Iaz (90), Odaie (10), Odae (13), Pădure (562), Poiană (364), Pîrău (907), Rîleț (17) etc. Pentru astfel de nume 
„,nu este suficientă explicaţia, spre exemplu, a numelor de familie Balta, Bolovan, Codruț etc. prin baltă „o apă mică stătătoare”, bolovan „o piatră mai mare” și codruț „o pădure mai mică”, ci trebuie mai ales să se determine valoarea apelativă a fiecărui nume, să se cunoască de ce un substantiv ca baltă, bolovan, codruț a fost dat unei persoane" (Goicu, 1996, p. 49).

După cum am prezentat, de la toponime cu sufixul -eanu se formează derivate, care indică originea locală. La început, aceste derivate au circulat ca supranume, iar mai târziu au devenit nume de familie consacrate. Acest tip de derivate se formează prin două modele:

a) toponim + sufix, fără alternanțe fonetice în punctele de îmbinare a morfemelor: Bordeianu, Brăviceanu, Brăileanu, Brătuşanu, Bârlădeanu, Bujoreanu, Glodeanu, Codreanu, Cojuşneanu, Lozovanu, Lăpuşneanu, Măgureanu, Nistreanu, Slobozeanu etc.

b) toponim + sufix, cu alternanțe fonetice în punctele de îmbinare a morfemelor: Bulboaca $>$ Bulboceanu, Palanca $>$ Palancianu etc.

Alte derivate cu valoare locală, ce e drept, foarte rar atestate, sunt cele formate cu sufixele:

-ar: Bahnar (var. Bahnari, Bahnaru), Baltaru (var. Baltari), Câșlaru (var. Cîş̧lar, Cîşlari, Cîş̧laru, Cîş̧lariu), Coşar (< coşar „locuință ciobănească”), Luncar (<luncar ,persoană care trăiește, locuiește în luncă”; var. Luncaru, Luncari), Odarii, Moțar, Poienaru (var. Poenaru), Șurar (var. Șuraru) etc. Iorgu Iordan explică de ce aceste nume s-au format cu alte sufixe decât cu -eanu: ,ceea ce face ca la cuvintele de felul celor notate mai sus să se alipească alt sufix decât -ean pentru indicarea originii locale este foarte probabil, principiul comodității. Bădeni, primitivul lui Bădenar, are deja pe -ean; tot aşa este simţit şi numele topic Poiana, deşi terminaţia acestuia seamănă cu -ean numai ca sunete. La Matca $\mathrm{n}$-ar fi fost potrivită cu spiritul limbii o terminaţie -cean sau -can, care se întâlneşte numai foarte rar." (Iordan, 1921, p. 259). Sextil Puşcariu consideră că sufixul -ar, care indică originea locală, s-a născut prin disimilare din sufixul -an (Puşcariu, 1921, p. 327), părere combătută de I. Bărbulescu, care susține că sufixul -ar și sufixul -an sunt sufixe total diferite (Bărbulescu, 1923, p. 274).

-aș/-eș: Colibaș, Luncaș (var. Luncașu, Luncasu), Mătcaș (var. Matcaș), Tîrleș etc.;

-еscu: Brăilescu, Codrescu, Copăcescu, Oltenescu, Pănășsescu, Pîrlișescu, Railescu etc.

După „lege”, derivatele cu sufixele -ar, -aș/-eș, -escu, în cazul când provin de la toponime, ar fi trebuit să fie formate cu sufixul-eanu (Lunceanu, Olteneanu, Poieneanu etc.). 
Numele de familie provenite de la toponime reprezintă o parte considerabilă a onomasticonului antroponimic. Crearea lor este determinată de anumite realități concrete și denotă o relație strânsă dintre toponim și antroponim.

Deși, prin origine și structură, sunt rezultatul evoluției societății noastre, majoritatea reprezentând derivate specifice limbii române totuși, în virtutea condițiilor istorice, unele nume de familie au fost derivate și/ sau amplificate cu câte un al doilea sufix, în special de origine slavă: Odainic, Odaiski, Poianschi, Plopschii, Budeanschi, Nistreanov, Pruteanov, Munteanov, Olteanov, Ungureanova etc., prin care se urmărea estomparea originii lor românești și încadrarea lor în onomasticonul rusesc.

Cercetarea numelor de familie derivate din toponime prezintă un interes deosebit, pentru că păstrează în structura lor vechi denumiri de locuri și localități, care în timp au dispărut sau și-au schimbat denumirile. Atestarea lor însă în nume de familie ne sporește convingerea absolută de băștinași dintotdeauna pe aceste locuri.

\section{Referințe bibliografice:}

1. Bărbulescu, I. Sufixele -ăţ, -ar şi -an arătând originea locală. În: Arhiva. Organul Societăţii ştiinţifice şi literare din Iaşi, 1923, nr. 1, p. 274.

2. Dauzat, Albert. Les noms de personnes, Paris, 1928.

3. Dron, Ion. Visterniceni. În: Curierul de seară, 1995, 6 mai.

4. Eremia, Anatol. Nume de localităţi. Studiu de toponimie moldovenească. Chişinău, 1970.

5. Goicu, Viorica, Goicu-Cealmof, Simona. Originea numelui de familie Muntean(u). În: Analele Universității de Vest din Timişoara, 2010, vol. XLVIII, p. 170-178.

6. Goicu, Viorica. Nume de persoane din Ţara Zarandului. Timişoara: Editura Amphora, 1996.

7. Iordan, Iorgu. Sufixele -ar şi -aş indicând originea locală. În: Arhiva. Organul Societăţii ştiințifice şi literare din Iaşi. Iaşi, 1921, nr. 2, p. 259.

8. Pascu, G. Sufixele româneşti. Bucureşti, 1916.

9. Paşca, Şt. Nume de persoane şi nume de animale în Ţara Oltului. București, 1936.

10. Pașca, Ștefan. Sufixe care indică apartenența locală. În: Dacoromania, Cluj, 19311933, vol. VII, p. 154-163.

11. Popescu, Magdalena. Nume de locuitori derivate de la teme străine. În: Studii și materiale privitoare la formarea cuvintelor în limba română, 1960, vol. II, p. 213-224.

12. Puşcariu, Sextil. Câteva cazuri de asimilare și disimilare în limba română. În: Dacoromania, Cluj, 1921, vol. I, p. 322-330.

Notă: Articolul a fost realizat în cadrul proiectului de cercetare 20.80009.1606.01 Valorificarea științifică a patrimoniului lingvistic național în contextul integrării europene, Institutul de Filologie Română „B. P.-Hasdeu” al MEC. 